\title{
The Expressive Forms of Natural Imagery in Chinese Poetry
}

\author{
Qiuping Wang \\ Faculty of Chinese Language and Culture, Guangdong University of Foreign Studies, Guangzhou, China \\ Email: wangqiuping213@sina.com
}

How to cite this paper: Wang, Q. P. (2017). The Expressive Forms of Natural Imagery in Chinese Poetry. Advances in Literary Study, 5, 17-21.

http://dx.doi.org/10.4236/als.2017.51002

Received: November 29, 2016

Accepted: January 16, 2017

Published: January 19, 2017

Copyright $\odot 2017$ by author and Scientific Research Publishing Inc. This work is licensed under the Creative Commons Attribution International License (CC BY 4.0).

http://creativecommons.org/licenses/by/4.0/

\begin{abstract}
Lyric is a mainstream for Chinese ancient literature. Chinese sages have realized that the main emotion cannot be expressed truly and vividly only by simple language in Pre-Qin period. Moreover, language cannot express our thought completely, so we need to utilize specific images. "Image" in ancient poems has long remained at the level of "natural scenery"; everything rises and falls, so nothing fails to affect people's feeling and inspiration. So this paper tries to illustrate the performance of natural images in Chinese poetry. The finding by analysis is that there are two main existing forms of images in poetry. One side is parallel existence, for example Parallel Existence of life Changes and social events; another side is contrast existence, such as contrast of four seasons and history. Papers will be mainly based on the argument from two aspects of parallel and contrast existence analysis.
\end{abstract}

\section{Keywords}

Natural Imagery, Poetry, Expressive Forms

\section{Introduction}

Lyric is a mainstream for Chinese ancient literature. Chinese sages have realized that the main emotion cannot be expressed truly and vividly only by simple language in Pre-Qin period. Confucius has ever said: "Language does not give the fullness of the concept in our mind." These show that the ancient have realized that "specific images" are used for "expressing meanings". Moreover, language cannot express our thought completely, so we need to utilize specific images. Liu Xie (c465-520) (Dragon-Carving and the Literary Mind. Beijing: Foreign Language Teaching and Research Press, 2003) is the first person to combine "meaning" with "image" in his works, which can be expressed as "with a mind of 
unique perception, one can wield the writing-brush to capture images. This is the foremost art of writing and a main feature of composition". His "image" is a result of "an integration of mental and physical world". In his opinion, "If at this moment the writer ascends a hill, his feeling will permeate the mountain. If he faces sea, his emotion will overflow sea". "Image" in ancient poems has long remained at the level of "natural scenery", but until Zhong Rong (?-c513) (Grades of poetry, Beijing: People Press, 2011) creatively expanded its meaning to the level of social events in his Poetry. Lu Ji (262-303) (Lu Ji's rhyming, Shanghai: Chinese publishing, 1997) in his Lyrics, points out that everything rises and falls, so nothing fails to affect people's feeling and inspiration. He tries to illustrate the performance of natural images in Chinese poetry.

\section{Parallel Existence}

In Chinese literature, we can see that most poets often regard nature as the same thing as life. It is connected with Chinese ancient philosophy. In ancient times, it was unbelievable to contend with nature. "Unity of Man and Nature" is the philosophy foundation of parallel existence between life and natural. Its performance is as follows.

\subsection{Parallel Existence of Life Changes}

Chinese poets think that natural changes in four seasons are parallel to life changes. Throughout the year, sensitive Chinese poets always associate seasonal changes with life changes, namely "spring, summer, autumn, winter" with "birth, growth, decline, death". They are different in cycle but similar in form. Therefore, there are lots of poems about spring and autumn. In Chinese poetry, autumn is a symbol of senile. In Tales of Woe, natural images have begun to appear: "The sun delayed and the moon sped fast, spring and autumn passed in swift succession; fallen flowers are scattered on the ground, dusk might come before my dream comes true". The poetry of Zuo Si (C250-305) (a famous poet of the Jin dynasty, born in Linzi of Qiguo, today is Linzi county, Shandong Province), "When autumn comes and summer passes, evening dew becomes morning frost. In due time the supple twigs do blight, the verdant leaves turn yellow overnight." Poets prefer to choose a series of natural images to express their emotions, for example, "When my prime of life is forever gone, in my old age my sighs will linger on." They realize natural changes, which agitate their emotions and strengthen creative passion. So it can also be called "It is natural sight that inspires poets' inspiration. Natural changes lead spiritual changes". It is just because poets consider natural changes as mental changes. That's why so many natural images about four seasons have been used as "images" in Chinese poetry.

\subsection{Parallel Existence of Social Events}

Not only life and natural change but also everything on earth has similar identity. Liu Ruoyu (2001), in his Art Essence of Chinese Literature (Beijing: People 
Press), points out that "The concept of nature, as a congenial object of life, is evident in the earliest Chinese poems, the Book of Songs." He takes Kwan Tzeu as an example, considering that this poem is using "Kwan" to express a gentleman's love and pursuit to a girl. This is also a similarity between animal courtship and human love, so we are easily excited by natural sceneries.

What's more, in The Nineteen Chinese Poems, a poem is "Bright light shines the moon in the sky, shedding light upon the bed I lie. As I stay awake in moods of gloom, I walk around the room. Happy as you have been on your tour, you'd best return to practical life. I open the door and pace the yard alone, to whom can my deep sorrow be made known? I gaze in vain and come back in deep distress, shedding tears upon my dress". In the poetry, author's friend who once was together with the author now has success in his life. The author hopes that his friends can help him in his career, but his friend treats him as a stranger, leaving him behind. When the author encounters this event, everything is in his color. There is also another poem, "The millennium with weeds, season and after they are easy. Autumn cicadas trees, fence has gone overlooking a comfortable?". The author sees the same change between autumn scenery and personal experience. Autumn is a season by the tide of life transition, because it ends the prosperity in summer, and will usher the chill in winter. The advent of autumn also heralds a beautiful season coming to an end. Then the poet cites another examples in The Book of Songs, namely "There is Sieve in the south, which is useless to sift; there is Ladle in the north, which lades out no liquor", and "Brilliant shines draught oxen, there is Lucifer in the east". The poet uses a series of images to express his inner frustration and resentment.

Poets realize images in nature are identical with life, so they often feel that "They stir in response to the environment. It is natural that people will express themselves when emotions stir", which makes natural scenery become good images.

\section{Contrast Existence}

Chinese poets find nature as a similar thing in life, also find it as a contrast thing with life. The contrast is not a reference of man and nature, but a contrast made between life and natural changes in different ways, even though they all obey the same rule.

\subsection{Contrast of Four Seasons}

The contrast of four seasons is an endless natural change while the life change has gone forever. When poets compare seasonal and life changes, they fell very sad because seasonal change is cyclic, but life change has gone forever. Taking seasonal changes as examples in Chinese poetry is quite common. Cui $\mathrm{Hu}$ (?-831) (a famous poet of the Tang dynasty, born in Linbo, today is Dingzhou county, Hebei Province) said that "In the house on the day last year, a pink face vied. In beauty with the pink peach blossoms side by side. I don't know today where the pink face has gone; in vernal breeze still smile pink peach blossoms 
full-blown." Here the image of "pink peach blossoms" and "the beauty" is a comparison. Every year the pink peach blossoms are similar, but the pink face has gone, which represents four seasons are irrelevant with life when it changes endlessly. And in Zhang Ruoxu's (c647-730) (a famous poet of the beginning of Tang Dynasty) The Moon Over the River on A Spring Night, he issues such a painful sigh: "Who did first see the moon rise by the riverside? When did the moon first see a man by riverside? Many generations have come and passed away; from year to year the moon looks alike, old and new. Tonight we do not know for whom she sheds her ray, but hear the river say to its water adieu." The "river" and "moon" once again become a comparison of life, which causes poet's pain. The moon and the river can change, but life cannot keep a good state.

\subsection{Contrast of History}

Natural metabolism is the same with life. But natural metabolism, as a whole, shows endless characteristics. From a broad perspective, the cycle of nature is endless, and it is in sharp contrast to forever passing of human history. Some excellent poets in Chinese poetry use sharp contrast between natural scene and history to express their wishes. For example, in Wei Zhuang's (c836-910) (a famous poet of the late of Tang Dynasty, born in Chang'an, today is Xi'an county, Shanxi Province) A Picture of Jin Ling: "Over the riverside grass falls a drizzling rain; dynasties have passed like dreams, and birds cry in vain. Three miles along the dike unfeeling willows stand, adorning like a veil of mist the lakeside land." He uses some images like "drizzling rain", "riverside grass", "the dike" to express his sad feeling that dynasties have gone forever. In Liu Yuxi's (772-842) (an outstanding statesman and exiling poem in middle of Tang Dynasty, born in Luoyang, Henan Province) The Street of Mansions: "Beside the Bird Bridge rank grasses overgrow; over the street the setting sun hangs low. Swallows are skimmed by painted eaves in bygone days, are dipping now among the humble homes' doorways." In Li Bai's (701-762) (a romantic poet in the Tang Dynasty, who possessed a lofty position in the poetichistory) The Run of Yue Capital: "The king of Yue returned, having destroyed the foe; his loyal men came home, with silken dress aglow. His palace thronged with flower-like ladies fair; now we see but a frock of partridges flying there". We can see the poet makes a contrast between passing history and natural circulation by choosing a series of natural images. It is the circulation that agitates author's affection, so it can also be called emotional article, which means emotions are produced in artistic conception. That's why the author chooses so many natural scenes as images in Chinese poetry.

Nature is not eternal unchangeable in an absolute sense. Every part of nature is constantly changing, but as a whole, it presents characteristics of eternal cycle. So do the human beings. In terms of individuals, human beings are changing from birth to death, but as a whole, they are also in the circle of life from generation to generation. Chinese poets are more likely to compare individuals with overall nature to express their emotions. 


\section{Conclusion}

Natural images occupy a large proportion in Chinese poetry. Chinese poets have also paid their attentions to natural scene. It was not until the preface of Zhong Rong ${ }^{1}$ that pointed out the "things" included both natural scene and social life. Natural images appear in Chinese poetry in the form of parallel or contrast, to express Chinese poets" delicate "implication" or "personal ambition".

\section{Funding}

This project was supported by Innovative School Project in Higher Education of Guang Dong, China (program number: GWTP-LH-2015-05).

\section{References}

Liu, R. Y. (2001). Art Essence of Chinese Literature. Beijing: People Press.

Liu, X. (c465-520). Dragon-Carving and the Literary Mind. Beijing: Foreign Language Teaching and Research Press.

Lu, J. (262-303). Lu Ji's Rhyming. Shanghai: Chinese Publishing.

Zhong, R. (?-c513). Grades of Poetry. Beijing: People Press.

Submit or recommend next manuscript to SCIRP and we will provide best service for you:

Accepting pre-submission inquiries through Email, Facebook, LinkedIn, Twitter, etc. A wide selection of journals (inclusive of 9 subjects, more than 200 journals) Providing 24-hour high-quality service User-friendly online submission system Fair and swift peer-review system Efficient typesetting and proofreading procedure Display of the result of downloads and visits, as well as the number of cited articles Maximum dissemination of your research work

Submit your manuscript at: http://papersubmission.scirp.org/ Or contact als@scirp.org

${ }^{1}$ Zhong Rong (c468-518) is the famous literary critic in the Northern and Southern Dynasties. He was born in Yingchuan (today is Xuchang county, Henan Province). 